\title{
Consanguinity related prenatal and postnatal mortality of the populations of seven Pakistani Punjab cities
}

\author{
S A SHAMI*, L H SCHMITT $\dagger$, AND A H BITTLES
}

From * the Department of Biological Sciences, Quaid-i-Azam University, Islamabad, Pakistan; †Department of Biological Anthropology, University of Oxford, Oxford; and $¥ D$ Department of Anatomy and Human Biology, King's College London, London.

SUMMARY A retrospective study was conducted on prenatal and postnatal mortality among the populations of seven cities in the Pakistani province of Punjab. Consanguineous marriages were strongly favoured and the coefficients of inbreeding $(F)$ for the present generation in each locality ranged from 0.0236 to 0.0286 . There was a highly significant relationship between the degree of inbreeding and mortality, with most consanguinity related deaths reported in the neonatal, infantile, and childhood periods. The findings strongly suggest that consanguinity may play a major role in the high rates of postnatal mortality observed in Pakistani communities now resident in the United Kingdom.

The relationship between inbreeding and the health of human populations has long been a subject of major interest in medical genetics. Extensive studies in Japan, centred on Hiroshima and Nagasaki ${ }^{1}$ and later Fukuoka ${ }^{2}$ and Hirado, ${ }^{3}$ showed the extent and timing of inbreeding depression in those communities. While the frequency of consanguineous unions latterly has been declining in Japan, ${ }^{45}$ marriages contracted between close relatives remain popular in many other major human populations. In particular, high current levels of inbreeding have been reported among the predominantly Hindu peoples of south India ${ }^{6-9}$ and in a wide variety of traditionally Muslim communities ranging from Egypt $^{1011}$ and Kuwait ${ }^{1213}$ to Sudan, ${ }^{14}$ Iran, ${ }^{15}$ and the southern Republics of the USSR. ${ }^{16}$ The primary aim of the present study was to estimate the effects of inbreeding on prenatal and postnatal mortality in the almost exclusively Muslim population of the Pakistani province of Punjab. It was also envisaged that the information gained would be valuable in assessing the effects of consanguineous marriages on the overall health status of the sizeable Pakistani community resident in various regions of the United Kingdom.

†Present address: Department of Anatomy and Human Biology, University of Western Australia, Nedlands, Australia.

Received for publication 18 August 1988.

Revised version accepted for publication 4 October 1988.

\section{Subjects}

The basic data were gathered by retrospective interview in seven Punjabi cities between 1980 and 1983. Government of Pakistan estimates for the population sizes of the cities studied range from $49 \cdot 5$ thousand (Mianchannu) to 3.8 million (Lahore). The information for Lahore $^{17}$ and in part for Gujrat $^{18}$ was obtained from women questioned in hospital general and labour wards, while in the remaining five communities all data were collected by door to door interviews. ${ }^{19-22}$ The populations were subdivided by consanguinity class into double first cousin, first cousin, first cousin once removed, second cousin, and unrelated marriages, and also bradari relationships, that is, marriages between couples with a common surname. Details recorded for each marriage were the numbers and dates of all pregnancies, whether resulting in abortions (prenatal losses before 28 weeks' gestation), stillbirths, or livebirths. Postnatal deaths were recorded by age period as first month, months 2 to 12 , and years 2 to 8 (Lahore, Mianchannu, and Muridke) or two to 10 years (Sheikhupura, Gujrat, Jhelum, and Rawalpindi).

Among the bradari relationships there were both couples known to be consanguineously related to a remote degree and those who were unrelated. In their original reports Shami et al ${ }^{17-22}$ treated bradari 
relationships as effectively non-consanguineous. Under this convention the rates of inbreeding in each locality ranged from $37.8 \%$ (Mianchannu) to $48.9 \%$ (Sheikhupura), with coefficients of inbreeding (F) calculated for the present generation of Lahore 0.0269 , Mianchannu 0.0236, Muridke 0.0240, Sheikhupura 0.0271, Gujrat 0.0257, Jhelum 0.0262, and Rawalpindi 0.0286. As reliable information on the levels of inbreeding in previous generations was not available, although it is known that consanguineous marriages had been contracted, these estimates must be regarded as minimal. To avoid possible ambiguity when assessing the relationship between consanguinity and mortality in the present study, all bradari data were omitted from the statistical analyses.

\section{Methods}

The data were tested for inbreeding effect by a method based on multiple weighted regressions, ${ }^{23}$ using the Genstat statistical package (Rothamstead Experimental Station). The regression coefficients plotted from mortality data at differing levels of inbreeding allow a differentiation to be made between deaths expressed under random mating (A) and deaths arising from the expression of recessive genes via inbreeding (B). Total genetic load per gamete is therefore equivalent to the sum of $B$ and the genetic component of $\mathrm{A}$. Care is necessary in evaluating the absolute $A$ and $B$ values obtained by

TABLE 1 Number of marriages studied by consanguinity class.

\begin{tabular}{lcrrrrr}
\hline Locality & $D I C$ & $I C$ & $1 / 2 C$ & $2 C$ & Unrelated & Total No \\
\hline Lahore & 23 & 321 & 37 & 30 & 270 & 681 \\
Mianchannu & - & 51 & - & - & 19 & 70 \\
Muridke & - & 92 & 3 & - & 19 & 114 \\
Sheikhupura & - & 381 & 32 & - & 67 & 480 \\
Gujrat & 34 & 306 & 6 & 9 & 70 & 425 \\
Jhelum & 4 & 394 & 39 & 3 & 338 & 778 \\
Rawalpindi & 4 & 425 & 29 & 4 & 319 & 781
\end{tabular}

$\mathrm{DIC}=$ double first cousin $(\mathrm{F}=0.125) ; \mathrm{IC}=$ first cousin $(\mathrm{F}=0.0625) ; 11 / 2 \mathrm{C}=$ first cousin once removed $(\mathrm{F}=0.0313) ; 2 \mathrm{C}=$ second cousin $(\mathrm{F}=0.0156)$; unrelated $(\mathbf{F}=\mathbf{0})$. this method,${ }^{24}$ but its widespread usage in investigating the genetic load carried by human populations $\stackrel{5}{\stackrel{5}{\rightarrow}}$ makes it useful in comparative studies. All levels of $\overrightarrow{0}$ statistical significance attained were determined by Student's $t$ test.

\section{Results}

The number of marriages studied in each com- $\overrightarrow{0}$ munity is shown in table 1 , with mortality at each $\vec{\overrightarrow{ }}$ age expressed numerically and as proportions in ${ }_{\sigma}$ table 2. In table 3 the results from all cities aggregated by time period are presented as values of $\mathrm{A}$, mortality under random mating, and $\mathrm{B}$, deaths ô $^{\circ}$ ascribed to inbreeding measured as lethal equivalents $\rightarrow$ per gamete. $^{23}$ The A values were significantly ô greater than zero for all five age groups $(p<0 \cdot 001)$, V indicating considerable prenatal and postnatal $\frac{\circ}{2}$ mortality components owing to causes other than

TABLE 3 Mortality by age interval: $A$ and $B$ values for all localities combined.

\begin{tabular}{lllll}
\hline Age interval & $A$ & $\begin{array}{l}\text { Standard } \\
\text { error }\end{array}$ & $B$ & $\begin{array}{l}\text { Standard } \\
\text { error }\end{array}$ \\
\hline Abortions & $0.0456^{*}$ & 0.0034 & 0.051 & 0.066 \\
Stillbirths & $0.0302^{*}$ & 0.0029 & $0.297^{*}$ & 0.062 \\
$\begin{array}{l}\text { Deaths in 1 month } \\
\text { Deaths in months }\end{array}$ & $0.0183^{*}$ & 0.0023 & $0.239^{*}$ & 0.050 \\
$\begin{array}{l}2 \text { to 12 } \\
\text { Deaths in years }\end{array}$ & $0.0275^{*}$ & 0.0028 & $0.437^{*}$ & 0.064 \\
2 to 8/10 & $0.0292^{*}$ & 0.0029 & $0.324^{*}$ & 0.065 \\
\hline${ }^{*} \mathrm{p}<0.001$. & & & &
\end{tabular}

TABLE 4 Mortality by locality: $A$ and $B$ values for all ages combined.

\begin{tabular}{|c|c|c|c|c|}
\hline Locality & $A$ & $\begin{array}{l}\text { Standard } \\
\text { error }\end{array}$ & $B$ & $\begin{array}{l}\text { Standard } \\
\text { error }\end{array}$ \\
\hline Lahore & $0 \cdot 213 \ddagger$ & 0.023 & $2 \cdot 26 \ddagger$ & 0.54 \\
\hline Mianchannu & $0 \cdot 250^{*}$ & $0 \cdot 114$ & 1.86 & $2 \cdot 13$ \\
\hline Muridke & $0 \cdot 126^{*}$ & 0.057 & $1 \cdot 32$ & 1.08 \\
\hline Sheikhupura & $0 \cdot 138 \dagger$ & 0.034 & 1.02 & 0.63 \\
\hline Gujrat & $0 \cdot 146 \ddagger$ & 0.033 & $1 \cdot 27^{*}$ & 0.56 \\
\hline Jhelum & $0.088 \ddagger$ & $0 \cdot 012$ & $1.72 \ddagger$ & $0 \cdot 34$ \\
\hline Rawalpindi & $0 \cdot 170 \ddagger$ & $0 \cdot 018$ & 0.74 & 0.40 \\
\hline
\end{tabular}

${ }^{*} p<0.05 .+p<0.01 . \neq p<0.001$.

TABLE 2 Total number of conceptuses studied in each sample and proportion dying: from abortions to years 8/10.

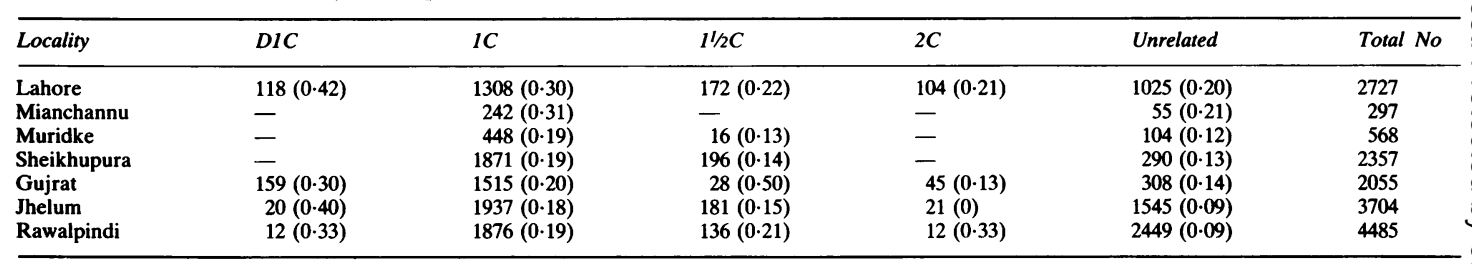


inbreeding. The values of $B$ for abortions and the three postnatal categories were homogeneous among populations, whereas the stillbirth data were heterogeneous. Abortions failed to show a significant inbreeding effect, but the other four age groups all indicated a highly significant consanguinity related increase in mortality $(p<0 \cdot 001)$.

The data on total mortality tabulated by individual locality, again subdivided into A and B components, are given in table 4 . The values for $A$ were significant for all seven cities, with the lowest levels attained in Mianchannu and Muridke $(p<0.05)$, the smallest data sets available, but they were highly heterogeneous among localities (F6,14=9.87, $\mathrm{p}<0.001)$. By comparison, $B$ values were homogeneous $(\mathrm{F} 6,14=1 \cdot 10)$ with an estimate for the mean slope of $1.412(p<0.001)$. However, when considered individually, the consanguinity related effects on total mortality attained significance in only three of the communities studied: Gujrat $(\mathrm{p}<0.05)$, Lahore $(p<0.001)$, and Jhelum $(p<0.001)$. To assess the timing of the recessive gene contribution to mortality, $B$ was subdivided by age group and locality (table 5). Negative B values were obtained for abortions in Gujrat and Rawalpindi and for postnatal deaths during the first month and months 2 to 12 in Muridke. Seven of the possible 30 community/age period combinations were significant at the 0.05 level: stillbirths in Lahore and Rawalpindi, deaths in the first month in Lahore and Jhelum, deaths during months 2 to 12 in Jhelum, and in years 2 to 10 in Jhelum and Rawalpindi.

With the exception of Rawalpindi, the consanguineous marriages tended to have more pregnancies (table 6), but none of the differences observed was statistically significant.

\section{Discussion}

A number of interesting features have emerged from the present study. Although the coefficients of inbreeding (F) calculated for the seven Punjabi cities, ranging from 0.0236 to 0.0286 , were very similar to those reported for south India, ${ }^{6-9}$ the patterns of inbreeding in the two regions varied markedly. In south India, Hindus, Christians, and occasionally Muslims contracted uncle-niece marriages $(F=0 \cdot 125)^{8}$; these were proscribed by Punjabi Muslims but double first cousin marriages $(F=0 \cdot 125)$ were permitted. Equally, the strong preference for cross-cousin marriages among Dravidian Hindus ${ }^{25} 26$ contrasted with the parallel first cousin unions predominating in Punjabi Muslims. $^{21} 22$

A highly significant overall association between inbreeding and mortality was shown in this large Punjabi population sample. However, non-availability of information on the relative socioeconomic status of the consanguineous and non-consanguineous marriages necessitates a degree of caution in

TABLE 5 Mortality by age interval and locality: $B$ values, estimated as lethal equivalents per gamete.

\begin{tabular}{|c|c|c|c|c|c|c|c|c|c|c|}
\hline Locality & Abortions & $\begin{array}{l}\text { Standard } \\
\text { error }\end{array}$ & Stillbirths & $\begin{array}{l}\text { Standard } \\
\text { error }\end{array}$ & $\begin{array}{l}\text { Deaths } \\
\text { Ist month }\end{array}$ & $\begin{array}{l}\text { Standard } \\
\text { error }\end{array}$ & $\begin{array}{l}\text { Deaths in } \\
\text { in months } \\
2 \text { to } 12\end{array}$ & $\begin{array}{l}\text { Standard } \\
\text { error }\end{array}$ & $\begin{array}{l}\text { Deaths } \\
\text { in years } \\
2 \text { to } 8 / 10\end{array}$ & $\begin{array}{l}\text { Standard } \\
\text { error }\end{array}$ \\
\hline Lahore & $0 \cdot 189$ & 0.232 & $0.948^{*}$ & $0 \cdot 241$ & $0.456^{*}$ & $0 \cdot 121$ & 0.541 & 0.205 & $0 \cdot 112$ & $0 \cdot 137$ \\
\hline Muridke & 0.005 & 0.037 & $0 \cdot 260$ & 0.030 & -0.031 & 0.036 & -0.031 & 0.036 & 0.995 & 0.206 \\
\hline Sheikhupura & 0.271 & 0.099 & 0.304 & 0.214 & $0 \cdot 160$ & $0 \cdot 157$ & 0.383 & 0.564 & 0.050 & 0.351 \\
\hline Gujrat & -0.112 & $0 \cdot 144$ & 0.087 & 0.090 & 0.376 & $0 \cdot 220$ & 0.457 & $0 \cdot 191$ & 0.515 & $0 \cdot 183$ \\
\hline Jhelum & 0.345 & 0.203 & 0.491 & $0 \cdot 167$ & $0 \cdot 167^{*}$ & 0.046 & $0.367^{*}$ & 0.068 & $0.197^{*}$ & 0.045 \\
\hline
\end{tabular}

*p<0.05.

TABLE 6 Consanguinity class and mean total pregnancies.

\begin{tabular}{|c|c|c|c|c|c|c|c|c|c|c|}
\hline \multirow[t]{2}{*}{ Locality } & \multicolumn{2}{|l|}{$D I C$} & \multicolumn{2}{|l|}{$1 C$} & \multicolumn{2}{|l|}{$1 / 2 C$} & \multicolumn{2}{|l|}{$2 C$} & \multicolumn{2}{|c|}{ Unrelated } \\
\hline & Mean & $\begin{array}{l}\text { Standard } \\
\text { error }\end{array}$ & Mean & $\begin{array}{l}\text { Standard } \\
\text { error }\end{array}$ & Mean & $\begin{array}{l}\text { Standard } \\
\text { error }\end{array}$ & Mean & $\begin{array}{l}\text { Standard } \\
\text { error }\end{array}$ & Mean & $\begin{array}{l}\text { Standard } \\
\text { error }\end{array}$ \\
\hline Lahore & $5 \cdot 13$ & 0.69 & 4.07 & $0 \cdot 17$ & $4 \cdot 65$ & 0.72 & 3.47 & 0.36 & 3.79 & 0.16 \\
\hline Mianchannu & - & - & $4 \cdot 78$ & 0.20 & - & - & - & - & $2 \cdot 89$ & 0.61 \\
\hline Muridke & - & - & $4 \cdot 86$ & 0.23 & - & - & - & - & 5.47 & 0.58 \\
\hline Sheikhupura & - & - & 4.91 & $0 \cdot 15$ & $6 \cdot 13$ & 0.58 & - & - & $4 \cdot 33$ & 0.34 \\
\hline Jhelum & $5 \cdot 00$ & 0.40 & 4.91 & 0.07 & $4 \cdot 64$ & 0.71 & $7 \cdot 00$ & $1 \cdot 20$ & $4 \cdot 57$ & 0.11 \\
\hline Rawalpindi & 3.00 & 0.71 & $4 \cdot 41$ & $0 \cdot 13$ & 4.69 & 0.52 & 3.00 & 1.35 & $4 \cdot 54$ & 0.15 \\
\hline
\end{tabular}

$\mathrm{D} 1 \mathrm{C}=$ double first cousin $(\mathrm{F}=0.1250) ; 1 \mathrm{C}=$ first cousin $(\mathrm{F}=0.0625) ; 11 / 2 \mathrm{C}=$ first cousin once removed $(\mathrm{F}=0.0313) ; 2 \mathrm{C}=\operatorname{second}$ cousin $(\mathrm{F}=0.0156) ;$ unrelated $(\mathrm{F}=\mathbf{0}$ ). 
assessing the absolute levels of mortality indicated in table 2 and calculated as lethal equivalents per gamete (B) in tables 3 to 5 . Although all seven cities were situated in the same region, there were marked differences in the values obtained for $\mathrm{A}$, deaths expressed under random mating, ranging from $0 \cdot 088$ in Jhelum to 0.250 in Mianchannu (table 4). Against this very variable 'environmental' background, when mortality caused by recessive gene expression (B) was tested at individual city level it attained statistical significance in three of the seven communities tested. In two of these three cities, Lahore and Gujrat, the data were wholly or partially derived from hospital inpatients.

The results obtained for abortions were equivocal but the collection of information on early prenatal losses is always difficult and failure to observe excess abortions in consanguineous marriages has previously been noted. ${ }^{27}{ }^{28}$ The heterogeneous nature of the stillbirth data was also in keeping with reports from many different human populations, ${ }^{29}$ and it would appear that with stillbirths the relative contributions of deleterious recessive genes and other genetic and non-genetic factors can vary considerably. It is noticeable that the largest recessive gene contribution to stillbirths was observed in Lahore (table 5), the only data set totally derived from hospital inpatients, which indicates that these particular pregnancies may have been regarded as being at high risk. Although the timing of postnatal mortality varied from city to city, with a minority attaining statistical significance, the overall levels were comparable in each community. The total levels of mortality owing to the expression of recessive genes were higher in the Punjabi population than those reported earlier in $\mathrm{Japan}^{13}$ and south India. ${ }^{6}$

Despite the increased postnatal mortality with inbreeding indicated by this survey, consanguineous marriages are favoured in the Pakistani population. Perceived social advantages are at least partially associated with their popularity. It also seems probable that, against the background of high infant mortality caused by infectious diseases and nutritional disorders, while individual families may exhibit gross levels of mortality or morbidity attributable to the expression of recessive genes the effects generally remain within socially acceptable limits for the population as a whole. A further contributory factor may be the greater overall fertility of consanguineous marriages (table 6), earlier observed in $\mathrm{Japan}^{3}{ }^{30}$ and in Muslim communities from north India. ${ }^{31}$ Whether this apparent enhanced fertility results from greater biological or social compatibility, or reproductive compensation acting to replace infants dying at an early age, remains to be clarified.

One aspect of the present study which has assumed increasing importance during the last two $\stackrel{\mathbb{P}}{=}$ to three decades relates to the migration of consan- $\vec{F}$ guineously related couples from developing to developed countries. In the United Kingdom attention has focused on poor health indicators associated $\frac{\bar{c}}{\omega}$ with the resident Pakistani community. ${ }^{32}$ Currently $\vec{\sigma}$

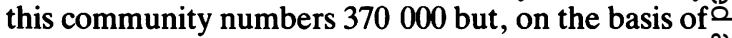
its age structure and age specific fertility rates, an $\%$ increase to a future total of approximately 850000 으 has been predicted. ${ }^{33}$ Concern has been specifically expressed on poor fetal growth, ${ }^{34}$ with high stillbirth $\vec{\omega}$ rates and infantile mortality, deafness, ${ }^{35}$ and congenital defects including central nervous system ${ }^{36} \widehat{Z}$ and complex cardiac anomalies, ${ }^{37}$ all of which appear to be overrepresented in the offspring of ${ }_{+}^{\circ}$ consanguineous marriages. The results of a recenti preliminary study conducted in Bradford showed 2 that consanguineous marriages continue to be con-응 tracted by Pakistani migrants at levels actuallyhigher than those of their parents, possible because $>$ of restricted choice in the numbers of suitable? marriage partners. ${ }^{38}$ The present report clearly $\vec{\bullet}$ shows that consanguinity, and the resultant expres-o sion of deleterious recessive genes, contributes sig-nificantly to infantile and childhood mortality in the population of the Punjab and an equivalent effect on morbidity could reasonably be expected. In the lighto of these findings and their implications for Muslim Punjabi populations in Pakistan and the United $\stackrel{\mathbb{Q}}{\circ}$ Kingdom alike, comparable studies on other inbred $\vec{\circ}$ Pakistani groups, for example from the North West 3 Frontier and Sind provinces, and from Bangladesh would merit priority attention. Their significance in? terms of future genetic counselling provision equally must be a matter for concern.

Financial assistance towards travel costs (AHB) was generously provided by the Overseas Development $\subseteq$ Administration, London.

\section{References}

1 Schull WJ, Neel JV. The effects of inbreeding on Japanese children. New York: Harper and Row, 1965.

2 Yamaguchi M, Yanase T, Nagano H, Nakamoto N. Effects of ${ }^{-0}$ inbreeding on mortality in Fukuoka population. Am J Hum Genet 1970;22:145-59.

3 Schull WJ, Neel JV. The effects of parental consanguinity and inbreeding in Hirado, Japan. V. Summary and interpretation Am J Hum Genet 1972;24:425-53.

4 Imaizumi Y, Shinozaki N, Aoki H. Inbreeding in Japan: results of a nation-wide study. Jpn J Hum Genet 1975;20:91-107. \&

5 Imaizumi Y. A recent survey of consanguineous marriages in Japan. Clin Genet 1986;30:230-3.

6 Rao PSS, Inbaraj SG. Trends in human reproductive wastage in relation to long-term practice of inbreeding. Ann Hum Genet 1979;42:401-13.

7 Rao PSS, Inbaraj SG. Inbreeding effects on fertility and sterility in southern India. J Med Genet 1979;16:24-31.

8 Bittles AH, Radha Rama Devi A, Savithri HS, Rajeswari S, 
Appaji Rao N. Consanguineous marriage and postnatal mortality in Karnataka, South India. Man (NS) 1987;22:736-45.

9 Radha Rama Devi A, Appaji Rao N, Bittles AH. Inbreeding and the incidence of childhood genetic disorders in Karnataka, South India. J Med Genet 1987;24:362-5.

${ }^{10}$ Habib Z, Böök JA. Consanguinity and the incidence of thalassaemia in Egypt. Hereditas 1983;99:215-7.

${ }^{11}$ Hafez M, El-Tahan H, Awadalla M, El-Khayat H, Abdel-Gafar $A$, Ghoneim $M$. Consanguineous matings in the Egyptian population. J Med Genet 1983;20:58-60.

12 Alfi OS, Chang R, Azen SP. Evidence for genetic control of non-disjunction in man. Am J Hum Genet 1980;32:477-83.

13 Al-Awadi SA, Naguib KK, Moussa MA, Farag TI, Teebi AS, El-Khalifa MY. The effect of consanguineous marriages on reproductive wastage. Clin Genet 1986;29:384-8.

14 Ahmed AH. Consanguinity and schizophrenia in Sudan. Br J Psychiatry 1979;134:635-6.

15 Naderi S. Congenital abnormalities in newborns of consanguineous and nonconsanguineous parents. Obstet Gynecol 1979 53:195-9.

16 Ginter EK, Garkavtzeva RF, Revazov AA. Population structure and hereditary diseases in Uzbekistan. In: Eriksson AW Forsius HR, Nevanlinna HR, Workman PL, Norio RK, eds. Population structure and genetic disorders. New York: Academic Press, 1980:327-37.

17 Shami SA, Zahida. Study of consanguineous marriages in the population of Lahore, Punjab, Pakistan. Biologia 1982;28:1-15.

${ }^{18}$ Shami SA, Hussain SB. Consanguinity in the population of Gujrat (Punjab), Pakistan. Biologia 1984;30:93-109.

19 Shami SA. Consanguineous marriages in Mianchannu and Muridke (Punjab), Pakistan. Biologia 1983;29:19-30.

20 Shami SA, Iqbal I. Consanguineous marriages in the population of Sheikhupura (Punjab), Pakistan. Biologia 1983;29:231-44.

${ }^{21}$ Shami SA, Minhas IB. Effects of consanguineous marriages on offspring mortality in the City of Jhelum, Punjab, Pakistan Biologia 1984;30:153-65.

22 Shami SA, Siddiqui $H$. The effects of parental consanguinity in Rawalpindi City (Punjab), Pakistan. Biologia 1984;30:189-200.

${ }^{23}$ Morton NE, Crow JF, Muller HJ. An estimate of the mutational damage in man from data on consanguineous marriages. Proc Natl Acad Sci USA 1956;42:855-63.

24 Makov E, Bittles AH. On the choice of mathematical models for the estimation of lethal gene equivalents in man. Heredity 1986;57:377-80.
${ }^{25}$ Rao PSS. Religion and the intensity of inbreeding in Tamil Nadu, South India. Soc Biol 1983;30:413-22.

${ }^{26}$ Hann KL. Inbreeding and fertility in a south Indian population. Ann Hum Biol 1985;12:267-74.

${ }^{27}$ Bittles AH. Inbreeding in human populations. J Sci Indust Res 1980:50:108-16.

${ }^{28}$ MacCluer J. Inbreeding and human fetal death. In: Porter IH, Hook EB, eds. Human embryonic and fetal death. New York: Academic Press, 1980:241-60.

29 Bittles AH, Makov E. Inbreeding in human populations: an assessment of the costs. In: Mascie-Taylor CGN, Boyce AJ, eds. Human mating patterns. Cambridge: Cambridge University Press, 1988:153-67.

30 Schull WJ, Yanase T, Nemoto H. Kuroshima: the impact of religion on an island's genetic heritage. Hum Biol 1962;34: 271-98.

31 Basu SK. Effect of consanguinity among North Indian Muslims. J Pop Res 1975;2:57-68.

${ }^{32}$ Lumb KM, Congdon PJ, Lealman GT. A comparative review of Asian and British-born maternity patients in Bradford, 1974-8. J Epidemiol Community Health 1981;35:106-9.

${ }^{33}$ Modell B. Interpretation and application of demographic data. In: Bundey S, Roberts DF, eds. Health and consanguinity in immigrant populations in Britain. Biology and Society 1988;5: 27-32.

${ }^{34}$ Honeyman MM, Bahl L, Marshall T, Wharton BA. Consanguinity and fetal growth in Pakistani Moslems. Arch Dis Child 1987;62:231-5.

${ }^{35}$ Hoyle ME. The additional problems faced by hearing-impaired children of Asian parentage. J Br Assoc Teachers Deaf 1980; 4:15-20.

${ }^{36}$ Gillies DRN, Lealman GT, Lumb KM, Congdon P. Analysis of ethnic influence on stillbirths and infant mortality in Bradford, 1975-81. J Epidemiol Community Health 1984;38:214-7.

${ }^{37}$ Gatrad AR, Read AP, Watson GH. Consanguinity and complex cardiac anomalies with situs ambiguus. Arch Dis Child 1984;59: 242-5.

${ }^{38}$ Darr A, Modell B. The frequency of consanguineous marriage among British Pakistanis. J Med Genet 1988;25:186-90.

Correspondence to Dr A H Bittles, Department of Anatomy and Human Biology, King's College London, Strand, London WC2R 2LS. 